\title{
Változó civil társadalom
}

\section{Nonprofit szervezetek az ezredforduló után}

Napjainkban a kommunikáció, a gazdaság, a technika, a technológia fejlődésének köszönhetően felgyorsult, globalizálódott világban élünk, ahol az egyén és egyéni érdekek túlzott szerephez jutnak, ezzel szemben egészen más értékrendet képviselnek az alulról szerveződő társadalmi képződmények és a nonprofit szervezetek. Hangsúlyozni kell a helyi, lokális közösségek jelentőségét, hiszen a civil társadalom „építőkövei”, hozzájárulnak az alapvető értékek átadásához, egy jól múködő helyi társadalom létrejöttéhez, a társadalmi, a gazdasági élet formálásához.

Hazánkban a rendszerváltozás óta eltelt két évtized alatt a nonprofit szektor jelentôs számbeli gyarapodáson és minőségi fejlődésen ment és megy keresztül, a helyét a magyar társadalomban még ma is keresi. Napjainkban a gazdasági válság és annak elhúzódása óriási terhet ró a társadalomra, a piaci és az állami szektor szereplóire. A nonprofit szféra talán még ennél is érzékenyebben reagál a megváltozott gazdasági helyzetre, ami forrásmegvonással és a múködési feltételek változásával jár, s ez nagyfokú rugalmasságot és innovációs képességet követel meg. A civil társadalom megerôsödését emellett a gyorsan változó jogi környezet is nehezíti, mely sok bizonytalanságot és bizalmatlanságot szül az állami és a civil szektor szereplői között. A publikáció ezt a változó és alakulóban lévô nonprofit szektort mutatja be az elmúlt tíz évre fókuszálva.

Az országban az 1980-as és 1990-es évek fordulóján végbement politikai, gazdasági és társadalmi átalakulás megnyitotta az utat a civil szféra kibontakozása elôtt, a korábbi gátak megszúnésével a fejlődés robbanásszerú volt. Egyre erősebben nyilvánultak meg azok a jelenségek, amelyek közösségi választ adtak a problémákra, szükségletekre. A nonprofit szektor létrejöttének egyik legfontosabb oka, hogy olyan új társadalmi igények jelentek meg, amelyeket sem az állami, sem a piaci szektor nem tudott biztosítani. A korábbi mindenható és gondoskodó állam viszszaszorulásával nemcsak igény, hanem szükség is volt a társadalom önszerveződéseinek egyre szélesebb tevékenységi kört felölelő feladatvállalására. Hazánkban a rendszerváltozást követően az állampolgároknak jóval nagyobb lehetôségük van arra, hogy közösségek formájában meghatározó szereplőivé váljanak a településeiket és térségeiket érintő feladatok alakításában (Kuti 1991, 1998).

A társadalmi szerveződések számos olyan pozitív tulajdonsággal rendelkeznek, melyek indokolttá teszik szerepüket a társadalmi, a gazdasági szerepvállalás terén:

- összekötő szerepet töltenek be, és információt képesek átadni a lakosság, az állami és a piaci szereplők között;

- alkalmasak arra, hogy a különböző társadalmi szereplók között a társadalmi tőkét és a bizalmat erősítsék; 
- tevékenységük fontos része az állami és piaci szektor kontrollálása, a társadalmi csoportok érdekeinek a védelme, képviselete;

- múködésükkel, figyelemfelhívással és nonprofit jellegükkel hozzájárulhatnak a közszolgáltatások minél magasabb színvonalú és szélesebb körben való elterjedéséhez;

- egyéni esetkezelésüknek köszönhetően elérnek olyan társadalmi csoportokat, amelyeket az állam és a piaci szereplők nem képesek;

- az alulról szerveződő civilek szerepvállalása révén a fejlesztések közelebb kerülnek az emberekhez, elfogadottá válnak;

- innovatív és multiplikáló funkcióval bírnak, tevékenységük rugalmas és költségkímélő

- könnyebben próbálnak ki új módszereket;

- jelentôs szellemi tőkét tudnak mozgósítani, szabad kapacitással bírnak, emellett olyan helyismereti és kapcsolati tôkével rendelkeznek, melyek pótolhatatlanná teszik őket a helyi ügyek szervezésében, a térségeiket érintő fejlesztésekben, pályázatírásban és kapcsolatépítésben;

- problémaérzékenység és rendszerszemléletû gondolkodás jellemzi tevékenységüket, és hosszú távú jövőképpel rendelkeznek;

- a decentralizáció, a nyilvánosság, a részvétel, a partnerség és a szubszidiaritás elvei a civil szervezetek bevonását igénylik a területi, települési problémák megoldásába. Az EU fejlesztésekre szánt támogatásai nem szerezhetők meg a civil szervezetekkel való együttmúködés hiányában.

\section{A nonprofit szektor a statisztikák tükrében}

A magyar harmadik szektor történetének leglátványosabb fejlődését a szervezetszám alakulása esetében mutatta, hiszen fejlődése a rendszerváltás utáni években egész 1997-ig töretlen volt ${ }^{1}$, ami leginkább az alapítványok esetében volt robbanásszerú, a kedvező adózási szabályoknak köszönhetôen. Ebben az időszakban a szervezetszám-gyarapodást segítette az 1994-ben bevezetett három új szervezeti forma: a közalapítvány, a köztestület és a közhasznú társaság.

1 A rendszerváltás éveiben bekövetkező jogi változások adták az alapját a szektor fejlődésének: az alapítvány jogintézményének megjelenése, Polgári Törvénykönyv módosítása, egyesülési törvény. 
1. táblázat: A nonprofit szervezetek száma Magyarországon 1989 és 2010 között

\begin{tabular}{|c|ccc|}
\hline Év & Alapítvány (db) & $\begin{array}{c}\text { Társas nonprofit } \\
\text { szervezet }(\mathbf{d b})\end{array}$ & Összesen (db) \\
\hline 1989 & 400 & 8396 & 8796 \\
\hline 1990 & 1865 & 14080 & 15945 \\
\hline 1991 & 6182 & 17869 & 24051 \\
\hline 1992 & 9703 & 20660 & 30363 \\
\hline 1993 & 11884 & 22778 & 34662 \\
\hline 1994 & 14216 & 25943 & 40159 \\
\hline 1995 & 15650 & 27133 & 42783 \\
\hline 1996 & 17109 & 28207 & 45316 \\
\hline 1997 & 18603 & 28762 & 47365 \\
\hline 1998 & 19225 & 28159 & 47384 \\
\hline 2000 & 19754 & 28417 & 48171 \\
\hline 2001 & 19700 & 27444 & 47144 \\
\hline 2002 & 16515 & 29748 & 46263 \\
\hline 2003 & 20295 & 28526 & 48821 \\
\hline 2004 & 21216 & 31806 & 53022 \\
\hline 2005 & 21817 & 33380 & 55197 \\
\hline 2006 & 22255 & 34439 & 56694 \\
\hline 2007 & 22464 & 35778 & 62407 \\
\hline 2008 & 23732 & 38675 & 64925 \\
\hline 2009 & 24096 & 40829 & 66145 \\
\hline 2010 & 23667 & 42478 & 587 \\
\hline & 23456 & & \\
\hline
\end{tabular}

Forrás: Nonprofit szervezetek Magyarországon, 2009: 28., Statisztikai tükör, Nonprofit szervezetek Magyarországon, 2010-es gyorsjelentés

1997-et követôen stagnálásra, majd azt követôen újabb növekedésre váltott. A civil szektor mindig is nagyon érzékenyen reagált a társadalmi, gazdasági környezetre és azok változásaira. 2003-ban megfordult az addig tapasztalható trend, a növekedési ráta megint emelkedésnek indult, a gyarapodás évente elérte a 3\%-ot. 2003 még egy szempontból kiemelendô dátum, hiszen ettől kezdve az egyesületek éves növekedési üteme meghaladta az alapítványokét. Az ezredfordulón bekövetkezett számbeli gyarapodás a világgazdasági helyzet javulásának is köszönhetô, egy viszonylag nyugodt növekedési időszak indult el, melynek pozitív hatása hazánkban is érezhetővé vált a szervezetek bevételének növekedésében, valamint jelentősen kibővültek a pályázati források az Európai Unióba történő belépésünknek köszönhetôen. Intenzív fejlődés, reményteljes időszak indult el, melyet a 2008-ban bekövetkezett gazdasági világválság és annak hatásai szüntettek meg. A szervezetek számában és bevételeinek alakulásában jelentôs csökkenés indult el, amelyek 2010-ben már világosan látszottak (KSH 2011: 9.).

2010-ben közel 65 ezer szervezet múködött hazánkban, egyharmaduk alapítványként, több mint 50\%-uk egyesületként, a nonprofit vállalkozások és a közala- 
pítványok aránya 3\% és $2 \%$, a szakmai munkáltatói és munkavállalói érdekképviseleteké 6\% (KSH 2011: 9.) (2. táblázat).

2. táblázat: A nonprofit szervezetek száma és megoszlása jogi formájuk szerint, 2009

\begin{tabular}{|c|c|c|}
\hline \multirow[t]{2}{*}{ Jogi forma } & \multicolumn{2}{|c|}{ A szervezetek } \\
\hline & száma & megoszlása \% \\
\hline Alapítvány & 22122 & 33,4 \\
\hline Közalapítvány & 1545 & 2,3 \\
\hline Egyesület & 35743 & 54,1 \\
\hline Köztestület & 324 & 0,5 \\
\hline Munkavállalói érdekképviselet & 1332 & 2,0 \\
\hline Szakmai, munkáltatói érdekképviselet & 2741 & 4,1 \\
\hline Nonprofit gazdasági társaság & 2199 & 3,3 \\
\hline Nonprofit intézmény & 37 & 0,1 \\
\hline Egyesülés & 102 & 0,2 \\
\hline Összesen & 66145 & 100,0 \\
\hline
\end{tabular}

Forrás: Nonprofit szervezetek Magyarországon, 2009: 30.

A szférában mindig is a civil jelleg dominált, a szervezetek 90 \%-a klasszikus civil szervezetként múködött, ugyanakkor megfigyelhető a KSH által szerkesztett generációs alszektorokat bemutató táblázat alapján, hogy míg a civil szervezetek aránya közel azonos a vizsgált időintervallumokban, addig az érdekképviseletek aránya folyamatosan csökkent, a „félállami” szervezeteké nőtt (3. táblázat).

3. táblázat: A nonprofit szervezetek megoszlása alapításuk ideje szerint, \%

\begin{tabular}{|l|ccc|}
\hline & $\begin{array}{c}\text { Klasszikus civil } \\
\text { Szervezetek }\end{array}$ & Érdekképviseletek & $\begin{array}{c}\text { Egyéb nonprofit } \\
\text { Szervezetek }\end{array}$ \\
\hline $2005-2009$ & 88 & 4 & 8 \\
\hline $2000-2004$ & 88 & 5 & 7 \\
\hline $1995-2000$ & 86 & 6 & 8 \\
\hline $1990-1994$ & 86 & 12 & 2 \\
\hline X-1989 & 90 & 9 & 1 \\
\hline
\end{tabular}

Forrás: Nonprofit szervezetek Magyarországon, 2009: 28.

A tevékenységi területeket nézve a szervezetek 55\%-a négy területen tevékenykedik: szabadidő és hobbi, oktatás, sport, valamint kultúra. A szolgáltatások terén múködő szociális, egészségügyi és kutatási célú szerveződések száma az utóbbi években nőtt, de a szektor szolgáltató jellege még nagyon gyenge lábakon áll. 2009-ben leginkább a szakmai, gazdasági érdekképviseletek száma csökkent, ami rossz hatással volt a tevékenységi struktúrára, amely még ma is a szabadidő szervezésére szakosodott leginkább (KSH 2009: 26.). 


\section{Területi, települési sajátosságok}

A társadalom életében, a településhálózat minden szintjén kiemelkedő szerepe van a nonprofit szektor szerveződéseinek, számuk, szerepük, tevékenységi területük jól jelzi a helyi társadalom aktivitását, fogékonyságát a lokális problémák megoldására, kezelésére. Múködésükkel csökkenthetik az egyes településtípusok közötti társadalmi, gazdasági különbségeket, ellensúlyozzák az ebből adódó hátrányokat (Kákai 2009). A magyar nonprofit szektor településtípus szerinti sajátosságai - Budapest és vidék, város és község dichotómia - nagyon korán kirajzolódtak, élesen leképezték és ma is jelzik az egyre inkább mélyülő területi, települési különbségeket. A rendelkezésre álló statisztikai adatok idősorainak vizsgálata bemutatja a szektor területi, települési sajátosságait, illetve egy adott terület gazdasági fejlettsége, potenciálja és a nonprofit szervezetek közötti párhuzamot. A szektorban tapasztalt gyors számbeli gyarapodás, majd a lassú intenzív fejlődés nem egyforma mértékben érzékelhető az ország különböző területi egységeiben, településtípusaiban.

A területi jellemzőket vizsgálva elmondható, hogy ma a települések 9\%-ában nincs szervezet, 10\%-ában egy szervezet múködik, mindegyikük aprófalu. A társadalmi szerveződések településtípus szerinti eloszlása közel egyenletes, a különbségek csak a szervezeti formák tekintetében mutathatók ki. Budapesten az átlagosnál magasabb az adománygyưjtő alapítványok aránya, amely a források közelségével magyarázható, de kiugróan magas a nonprofit intézmények és az egyesülések száma. A közalapítványok gyakori előfordulása a községekben figyelhető meg, ennek célja a deficites önkormányzatok forrásainak bővítése. Az egyesületek megoszlása képezi le leginkább a népesség település szerinti arányait. A köztestületek a községek és kisvárosokra jellemzók, míg a nonprofit vállalkozások elsősorban a megyeszékhelyekre és a fővárosra (KSH 2009: 30.).

A különböző szervezeti formák területi aspektusai is megváltoztak a rendszerváltás óta. Az alapítványokra minden régióban a „relatív diffúzió” jellemző. A 1990-es évek elején a fővárosban és a Dél-Dunántúlon jött létre a legtöbb szervezet, addig napjainkra Budapest után Észak-Magyarország, Észak-Alföld és DélAlföld következik. Míg a Dunántúlon a településformák közötti eloszlás közel egyenletes volt, addig az Alföldön inkább a megyeszékhelyek és a városok lakossága hozott létre alapítványokat, a falvakra ez nem jellemző. A közalapítványok a Dunántúlra jellemzőek, leginkább az aprófalvas térségekre. Az egyesületek regionális megoszlása nagyobb eltéréseket mutat, mint az alapítványoké. Amíg a Dunántúlon található az összes egyesület egyharmada, addig az Észak-magyarországi régióban csupán egytizede. 2009-ben a nonprofit szervezetek egyharmada a KözépMagyarországi régióban múködött, de kiemelkedő adatokkal bír a három dunántúli régió is, melyek együtt tesznek ki annyi szervezetet, mint a Központi régió egymaga. A két alföldi régióban összpontosul a szervezetek egyötöde, Észak-Magyarországon a 12\%-a (KSH 2009: 33.). 
4. táblázat: Nonprofit szervezetek sûrúségi mutatói megyék és régiók szerint, 1993, 1999, 2009

\begin{tabular}{|c|c|c|c|c|c|c|}
\hline \multirow[b]{2}{*}{ Fơváros, megye, régió } & \multicolumn{2}{|c|}{1993} & \multicolumn{2}{|c|}{1999} & \multicolumn{2}{|c|}{2009} \\
\hline & $\begin{array}{c}\text { Szerveze- } \\
\text { tek meg- } \\
\text { oszlása } \\
(\%)\end{array}$ & $\begin{array}{l}\text { Ezer lakos- } \\
\text { ra jutó } \\
\text { szerveze- } \\
\text { tek száma } \\
\text { (db) }\end{array}$ & $\begin{array}{c}\text { Szerveze- } \\
\text { tek meg- } \\
\text { oszlása } \\
(\%)\end{array}$ & $\begin{array}{l}\text { Ezer la- } \\
\text { kosra jutó } \\
\text { szerveze- } \\
\text { tek száma } \\
\text { (db) }\end{array}$ & $\begin{array}{l}\text { Szerveze- } \\
\text { tek meg- } \\
\text { oszlása } \\
(\%)\end{array}$ & $\begin{array}{l}\text { Ezer lakos- } \\
\text { ra jutó } \\
\text { szerveze- } \\
\text { tek száma } \\
\text { (db) }\end{array}$ \\
\hline Budapest & 28,2 & 4,9 & 27,1 & 7,1 & 17,2 & 9,4 \\
\hline Pest & 6,4 & 2,3 & 7,3 & 3,4 & 12,3 & 5,6 \\
\hline Közép-Magyarország & 34,6 & 3,6 & 34,2 & 5,8 & 29,4 & 7,8 \\
\hline Fejér & 3,2 & 2,6 & 2,9 & 3,3 & 4,3 & 5,3 \\
\hline Komárom-Esztergom & 3,0 & 3,3 & 2,8 & 4,4 & 3,1 & 5,0 \\
\hline Veszprém & 4,4 & 4,0 & 4,6 & 5,9 & 3,6 & 7,9 \\
\hline Közép-Dunántúl & 10,6 & & 10,3 & 4,5 & 11,0 & 6,1 \\
\hline Győr-Moson-Sopron & 4,1 & 3,4 & 4,0 & 4,1 & 4,5 & 5,9 \\
\hline Vas & 2,7 & 3,4 & 2,8 & 5,1 & 2,6 & 6,8 \\
\hline Zala & 3,5 & 4,0 & 3,6 & 5,3 & 2,9 & 7,1 \\
\hline Nyugat-Dunántúl & 10,3 & & 10,4 & 5,1 & 9,9 & 6,5 \\
\hline Baranya & 4,4 & 3,7 & 3,9 & 4,7 & 3,9 & 7,0 \\
\hline Somogy & 4,6 & 4,7 & 4,2 & 6,0 & 3,2 & 7,5 \\
\hline Tolna & 1,9 & 2,6 & 2,5 & 4,9 & 2,3 & 7,2 \\
\hline Dél-Dunántúl & 10,9 & & 10,6 & 5,2 & 9,5 & 7,2 \\
\hline Borsod-Abaúj-Zemplén & 5,0 & 2,3 & 5,8 & 3,8 & 6,9 & 6,0 \\
\hline Heves & 3,1 & 3,3 & 3,2 & 4,8 & 3,1 & 6,8 \\
\hline Nógrád & 2,4 & 3,7 & 1,7 & 3,7 & 2,0 & 6,6 \\
\hline Észak-Magyarország & 10,5 & & 10,8 & 4,1 & 12,1 & 6,3 \\
\hline Hajdú-Bihar & 4,0 & 2,5 & 4,4 & 3,9 & 5,4 & 5,7 \\
\hline Jász-Nagykun-Szolnok & 3,9 & 3,2 & 3,6 & 4,2 & 3,9 & 4,9 \\
\hline Szabolcs-Szatmár-Bereg & 3,7 & 2,3 & 3,8 & 3,2 & 5,6 & 4,9 \\
\hline Észak-Alföld & 11,6 & & 11,8 & 3,7 & 14,9 & 5,2 \\
\hline Bács-Kiskun & 4,6 & 3,0 & 4,4 & 4,0 & 5,3 & 5,4 \\
\hline Békés & 3,5 & 3,0 & 3,6 & 4,4 & 3,7 & 6,2 \\
\hline Csongrád & 3,4 & 2,7 & 3,8 & 4,4 & 4,2 & 6,3 \\
\hline Dél-Alföld & 11,5 & & 11,9 & 4,2 & 13,2 & 5,9 \\
\hline Összesen & 100,0 & 3,4 & 100,0 & 4,8 & 100,0 & 6,6 \\
\hline
\end{tabular}

Forrás: Nonprofit szervezetek Magyarországon, 1993, 1999, 2009

Megyei megoszlás alapján a legtöbb szervezet a fővárosban és Pest megyében végezte munkáját, de kiemelkedik Borsod-Abaúj-Zemplén és Hajdú-Bihar is. A legkevesebb szervezet Tolna, Nógrád és Komárom-Esztergom megyékben múködik. Azonban csupán a szervezetszámokat figyelembe véve torz képet kapunk a szektor jellegzetességeiről, pontosabb adatokkal számolhatunk, ha figyelembe vesszük egy-egy területi egység népességszámát is. Kiemelkedően magas az ezer lakosra jutó szervezetek száma Veszprém, Somogy, Zala megyékben, ellenkezó tendencia jelenik meg Komárom-Esztergom, Jász-Nagykun-Szolnok és Szabolcs-Szatmár megyékben. A szervezetek területi elhelyezkedésére és lakosságszámára vonatkozó adatok azt mutatják, hogy nonprofit szervezetek nagyobb számban koncentrálód- 
nak a fővárosban és a három dunántúli régióban, mint az északi országrészben és az Alföldön. Ez leginkább a régiók eltérő társadalmi, gazdasági helyzetére, történeti és kulturális hagyományaira vezethető vissza, valamint fontos az állami szektor támogatókészsége is az adott területi egységben (KSH 2009: 33.).

\section{Gazdasági háttér}

A nonprofit szervezetek 90\%-ának volt bevétele 2010-ben, melynek területi eloszlása esetében csökkent a főváros koncentrációja, de még ennek ellenére is változatlanul magas a budapesti szervezetek részesedése. A hagyományos szerepköröket ellátó szervezetek (szabadidő, hobbi, kultúra) bevétele változatlanul alacsony, javult viszont a gazdaság, a környezet, a településfejlesztéssel foglalkozó társadalmi szerveződések pénzügyi helyzete.

A gazdasági válság hatására átalakulóban van a szektor bevételi szerkezete, folyamatosan csökken az államitól származó források mértéke, nőtt a magántámogatások aránya, amelyet a külföldről érkező források növekedése biztosít. Ennek legfőbb oka, hogy a kedvezőtlen pénzügyi környezetben a szervezetek tudatosabban pályáznak, és az évek során javult a pályázatok kihasználása is (KSH 2011: 90.).

A pályázati források esetében jelentős törvényi változás is történt a 2011-es év végén. A Nemzeti Civil Alapot a Nemzeti Együttmúködési Alap váltotta fel, amelyet több tekintetben bizonytalanságot és változást hozott a társadalmi szerveződések életében: csökkenő civil kontroll és állami támogatás, erôsödő politikai befolyás, közhasznúsági kategória változása. ${ }^{2}$

A rendkívüli gazdasági helyzet hatására a szervezetek igyekeznek belső forrásaikat növelni, szolgáltató tevékenységek irányába nyitni, több lábon állni és így átvészelni a válságos időszakot, amely minőségi változást is hoz a szférán belül.

\section{Humánerốforrás}

2009 és 2010 között közel 10\%-kal növekedett a munkavállalók száma a szektorban. A fóállásban, teljes munkaidőben foglalkoztatottak száma 2010-ben elérte a 96 ezer főtt, a munkavállalók 70\%-a nonprofit vállalkozásoknál, 13\%-a egyesületnél, 12\%-a magán- és közalapítványnál dolgozott. A fizetett alkalmazottak kétharmada a fővárosban és a megyeszékhelyen múködő nonprofit szervezetnél tevékenykedett, több mint fele felsőfokú végzettségú és nő, magas a nyugdíjasok száma is. Az önkéntes segítők becsült száma 418 ezer volt 2010-ben, akik 53 millió munkaórát dolgoztak az évben, amely 25 ezer fóállású foglalkoztatott munkaidejének felel meg (KSH 2011: 90.).

2 A Civil Törvény 2012. január 1-jén lépett életbe. 2011 CLXXV-es számú törvény az egyesülési jogról, a közhasznújogállásról, a civil szervezetek múködéséról és támogatásáról. 


\section{Összegzés}

Napjaink civil társadalma rengeteg kihívással és nehézséggel néz szembe: jelentősen megváltoztak a gazdasági és társadalmi feltételek, a jogi környezet gyorsan változik, így nehezen követhetô. A szervezetek többségének múködési problémái vannak. Az egyetlen lehetőség a túlélésre a szektor elónyeinek a kihasználása és a szolgáltatásbővítés lehet.

\section{Hivatkozott irodalom}

KÁKAI LÁsZLó (2009): Civil szervezetek regionális összefüggései. Civil Szemle 6 (1-2), 130-145.

KuTi Éva (1991): A nonprofit elméletek tanulságai és a nonprofit gyakorlat lehetőségei Magyarországon. Közgazdasági Szemle (1), 18-30.

KuTi Éva (2008): Stratégiai cselekvésen innen, illúziókon túl. Régi problémák és új kihívások Magyarország civil társadalmában és nonprofit szektorában. Civil Szemle 8 (4), 5-43.

KSH (2011): A nonprofit szektor legfontosabb jellemzői 2010-ben. Statisztikai Tükör 5 (90), 3.

Nonprofit szervezetek Magyarországon (Társadalomstatisztikai Közlemények) 1994, 1995, 1996, 1997, 1998, 1999, 2000, 2003, 2004, 2005, 2006, 2007, 2008, 2009. Budapest, Központi Statisztikai Hivatal. 